

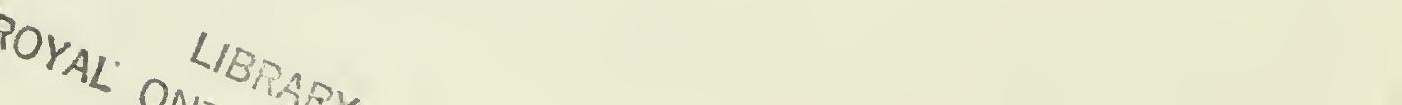




\section{Digitized by the Internet Archive in 2011 with funding from University of Toronto}




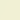





\section{CONTRIBUTIONS OF THE}

ROYAL ONTARIO MUSEUM OF ZOOLOGY

No. 23: THE SUMMER BIRDS OF THE NORTHEAST SHORE OF LAKE SUPERIOR, ONTARIO. By J. L. BAILLIE JR. AND C. E. HoPe. 



\title{
THE SUMMER BIRDS OF THE NORTHEAST SHORE OF LAKE SUPERIOR, ONTARIO
}

\author{
By J. L. Baillie, Jr. and C. E. Hope
}

\section{INTRODUCTION}

In continuation of the Museum's survey of the avifauna of Ontario, commenced in 1923, work was carried on in the summer of 1936 along the Canadian Pacific Railway adjacent to and eastward from the northeast shore of Lake Superior. Camps were established at three localities, approximately sixty miles apart, and a period of two weeks was spent at each. At Rossport the party collected from May 27 to June 9; from June 9 to 23, work was continued at Peninsula and the survey was completed at Amyot where a stay was made from June 23 to July 7 .

Rossport is a small fishing village with a population of about two hundred persons. Peninsula consists of but a station and several houses inhabited by railway men and their families. Amyot lies inland (east) about fifty miles from Lake Superior, and, like Peninsula, is but a station with a few houses mainly occupied by railroaders.

The topography of the region is bold and irregular and "the geological structure consists of pre-Cambrian granites with areas of late preCambrian iron slates, sandstones, and conglomerates, with block faulting and even diabase intrusion". (Halliday, 1937.) Along the lakeshore the hills rise abruptly to a height of 200 feet in some places. Along these hills, terraces and lacustrine deposits from Lake Algonquin and its predecessors are readily perceived. The altitude inland at Amyot is 1,382 feet above sea-level; at Rossport, 646 feet (Lake Superior, 602); and at Peninsula, 709. (White, 1916.)

The soil, which is composed of glacial deposits, is irregularly distributed. On high ground it is thin or wanting but there is a considerable accumulation in depressions. In no one place is the terrain eminently suited to agriculture.

The forest of the area is classified within the boreal forest region of Halliday (1937). It consists largely of white spruce, quaking aspen, and paper birch, with black spruce in the wet areas and jack pine on the drier hills. Minor components include balsam poplar, balsam fir, white cedar, tamarac, mountain maple, red osier dogwood and mountain ash. Fires have swept through the area under discussion on various occasions and have destroyed large tracts of forest and the accumulated humus which clothed the rock. 
Climatic conditions within the area surveyed are not markedly uniform. Factors which affect local temperature are the proximity to Lake Superior and altitude. Sharpe and Brodie (1931) state that "the average length of growing season, 67 days, is derived from three stations, two of which are adjacent to Lake Superior." For White River, twenty miles west of Amyot, the frost free period is only 37 days which "is as short as in any part of the province, giving rise to the more northerly type of forest." The interior position of this station, away from the moderating influence of the lake, and the high elevation, 1,225 feet, certainly would contribute to the cold temperatures recorded there in winter and also would shorten the period of growth in summer.

The area lies well within the Canadian life-zone of Merriam (see Snyder, 1938).

The personnel in the field in addition to the authors included $\mathrm{Mr}$. S. C. Downing, who contributed to the work with birds, and Mr. L. A. Prince, who concerned himself with mammals. To these gentlemen we extend our thanks for their assistance. Thanks are also due to Messrs. R. C. Brooman and P. Harrington, naturalists, who spent a fortnight with us in camp, for their cooperation. Particularly do we wish to acknowledge our indebtedness to the Canadian Pacific Railway, through Messrs. Percy Barr, H. A. MacDonnell and C. R. McQuown, agents respectively at Rossport, Peninsula and Amyot, for providing accommodation for our party. Other residents of the area helped considerably in the prosecution of our work and to all such persons we express our thanks. To Mr. L. L. Snyder, Assistant Director and Curator of Birds. of the Museum, we extend our thanks for his criticisms and suggestions offered during the preparation of the paper.

The only previous summer observations relative to birds within the area covered by this paper were made by Messrs. W. E. Saunders, Morris M. Green and J. Elliot Cabot (reported by Agassiz, 1850). Dr. Saunders made a short visit to Rossport in June, 1911, and Mr. Green spent the month of June, 1924, at Franz. Lists of birds seen have been supplied to the authors by these observers. Cabot accompanied Prof. Louis Agassiz's party along the Lake Superior shore through the area covered by this report between July 12 and 16 and August 2 and 6, 1848. Agassiz lists a few species observed at Pic and to the west of the Slate Islands. Species recorded by Agassiz but not accepted in the present paper are Wood Pewee and Field Sparrow. Sault Ste. Marie (Snyder, 1942), Lake Nipigon (Snyder, 1928), Port Arthur (Dear ,1940) and the upper Michipicoten River (Fargo and Trautman, 1930) are the nearest localities from which summer bird lists have been published.

One hundred and eighteen species of birds were listed during our field work, of which ninety-three were represented in the collection made. 


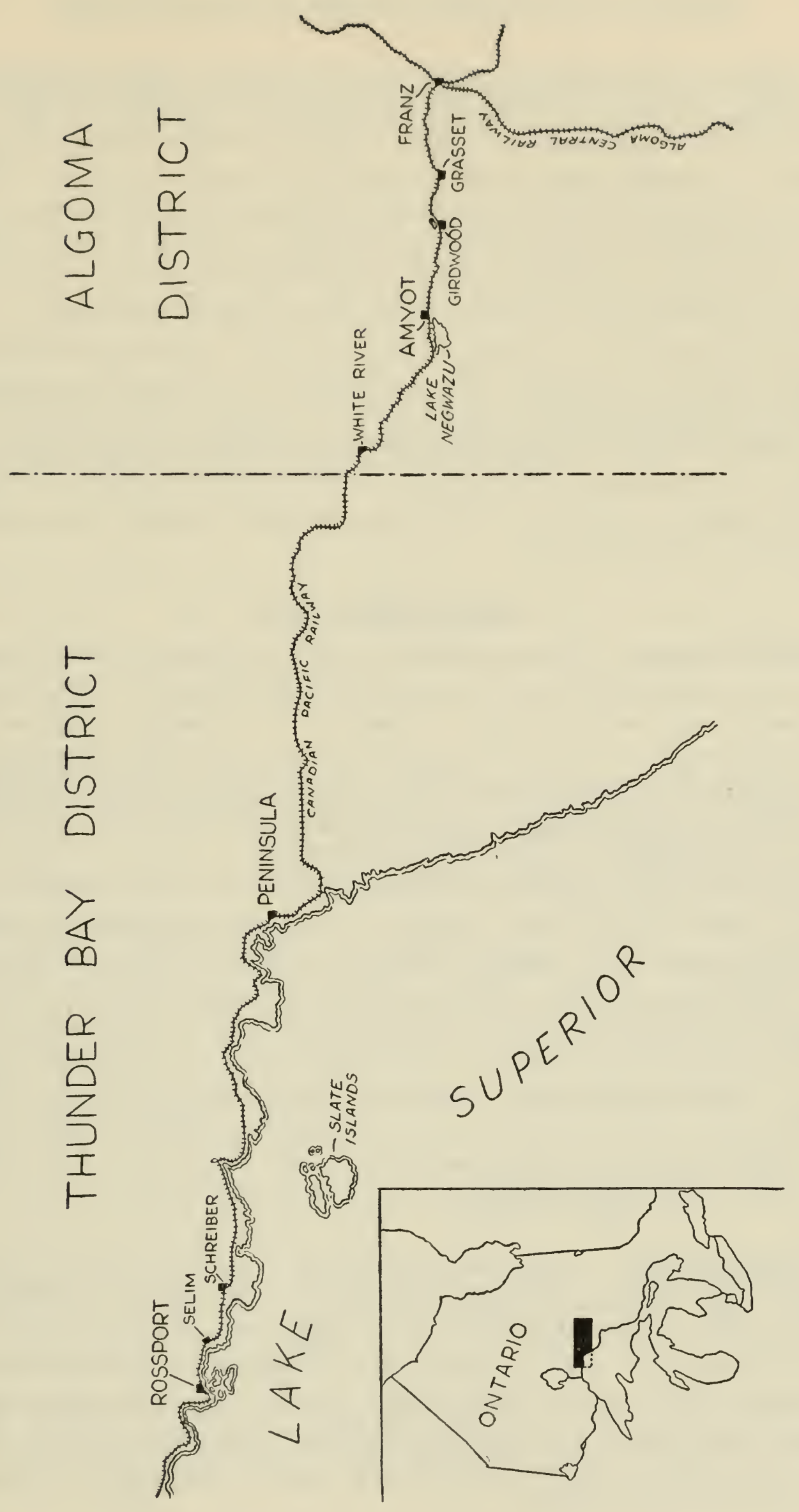


Six hundred and forty-three skins were preserved. Special attention in collecting was paid to forms the racial status of which have not been satisfactorily worked out in Ontario. Nestlings and juveniles of as many species as possible were taken though the necessary cessation of field work on July 7 somewhat curtailed this phase of the collecting. Four species (additional to the 118), seen by other observers are included in the list on their authority. These are Red-throated Loon, American Bittern, American Coot and American Three-toed Woodpecker.

The arrangement of the species and the Latin names are in accordance with the A.O.U. Check-List of N. A. Birds (1931). Since it has been our policy to treat the birds as species we have followed Taverner (1934) for the specific English names, which are not provided by the Check-List. It has been possible, in some cases, to discuss the subspecific status of certain species and where satisfactory conclusions have been reached these are stated in the text.

\section{ANNOTATED LIST}

Gavia immer. Common Loon.-A fairly common bird of the region. One to six individuals were recorded daily at Rossport. Not noted at Peninsula and seen sparingly at Amyot. No breeding evidence was secured though two seen on a small lake near Rossport behaved as if they might be nesting in the vicinity. Three specimens were brought to us while we were at Rossport by James Paulmert, who took them from gill nets at a depth of twelve fathoms (72 feet).

The two specimens did not differ significantly in size although one was a male and the other a female. Average measurements of these specimens are: Total length $-768 \mathrm{~mm}$., expanse- $1360 \mathrm{~mm}$., curve of wing-365 mm., culmen-78.5 mm., depth of culmen at nostril-22 $\mathrm{mm}$. They conform to the dimensions of the form, immer. The third specimen, a $q$, is considerably smaller. Its measurements are as follows: total length $-690 \mathrm{~mm}$., expanse- $1180 \mathrm{~mm}$., curve of wing $-328 \mathrm{~mm}$., culmen $-71.5 \mathrm{~mm}$., depth of culmen at nostril $-20 \mathrm{~mm}$. These measurements are within the range of size given for the form elasson.

$$
\begin{aligned}
& \text { o May 30, Selim } \\
& \text { क June 1, Rossport }
\end{aligned}
$$

Gavia stellata. RED-THROATED LoON.-Not observed or recorded by us. The fact that a female was taken on June 20,1911, at Rossport by Saunders (1922) suggests that the species might breed in the area under discussion. This is supported by a nest with two eggs found on a small rocky island in Lake Superior off Thunder Cape just seventy miles from Rossport, by L. S. Dear (Baillie and Harrington, 1936). More recently, Claude Garton of Port Arthur saw two adults with two young at Rossport in July, 1941. 
Botaurus lentiginosus. American BitTern.-A few individuals were seen at Franz in June, 1924, by Morris M. Green. It was not seen by us.

Anas rubripes. Black Duck.-A rare bird of the region due, no doubt, to the scarcity of marshes and other suitable habitat. Seen on one or two occasions at each camp, the largest number recorded for one day being three at Rossport. No specimens were taken and no breeding evidence was secured.

Mareca americana. BALdPate.-One noted on May 30 at Rossport was the only occurrence. Probably a belated migrant to its more westerly breeding grounds in the prairie provinces.

Nyroca collaris. RING-NECKED DuCK.-A male was noted at Amyot on June 30 on a small boggy lake. On July 7 one was recorded from the train on a small body of water near Girdwood, some ten miles east of Amyot. These observations, together with the knowledge that the species has become established in the east during recent years, indicate that the status of the Ring-necked Duck in this region is now that of a rare summer resident.

Nyroca affinis. Lesser Scaup Duck.-From May 31 to June 4 a male was noted regularly in a small bay of Lake Superior at Rossport. No suitable nesting habitat exists there. With consideration to the season when the bird was observed, it was probably a belated migrant.

Glaucionetta clangula. AmERICAN GoldEn-EYE.-This species was present at all our camps. It was recorded as not uncommon, especially at Rossport, where from one to six were seen almost daily. At Amyot a female and five downy young, not long hatched, were collected on June 26.

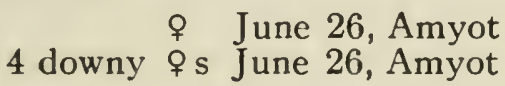

downy or June 26, Amyot

Clangula hyemalis. Old-squaw.-From May 28 to June 2 one to fifteen birds were recorded at Rossport daily. These were late migrants. None was encountered after June 2.

Melanitta deglandi. White-Winged ScoteR.-A flock of thirteen, apparently migrants, was noted on May 30 at Rossport. The species does not summer in this region.

Mergus merganser. Common Merganser.-Commonly met with at Rossport and Peninsula. Not recorded at Amyot. No breeding evidence was secured but the species is a common summer resident of the region as a whole. 
Mergus serrator. Red-ibeasted Merganser.-Observed at Rossport from May 27 to June 7. As many as thirty-one were recorded on May 30. No evidence that this species nests in this area was secured though two seen on June 21 at Peninsula suggested the possibility that they may breed in small numbers on the islands in Lake Superior. Inland at Amyot we did not record it.

A male was brought to us at Rossport by James Paulmert, who took it from a gill net set at a depth of twelve fathoms (72 feet).

$\sigma^{7}$ May 28, Rossport

Astur atricapillus. American Goshawk.-A rare summer resident of the region under consideration. No actual breeding evidence was secured. Single records were made at each of our three camps, an adult in each instance. In each case the observation was made in close proximity to where Ruffed Grouse were known to occur. At Peninsula, despite intensive field work locally, Ruffed Grouse were seen at only one spot. It was here that the Goshawk was encountered. In fact, the hawk was flushed from the ground where it had almost consumed a male of that species.

At Amyot, close to where a grouse was collected, our only Goshawk was seen.

The skull of an apparently immature male was secured at Rossport from a dessicated skeleton, probably the victim of a hunter's gun during the previous winter.

skull? 1935-6? Rossport

Accipiter velox. SharP-shinned Hawk.-A rare summer resident of the region; one or two recorded at each camp. At Peninsula a nest was found on June 9 twenty-five feet up in a white spruce in a spruce forest. It contained four slightly incubated eggs. A female, collected near the nest, was sexually mature but was still in the juvenile plumage, badly worn and bleached. No sign of the post-juvenal moult is evident.

In the vicinity of the occupied nest, four old nests of similar construction and similar situation were present, probably nests of previous years. On the ground, close to the nesting site the remains of a number of kills were detected. These consisted of a warbler, thrush and finch and at least three Red-backed Mice (Clethrionomys gapperi) and one Meadow Jumping Mouse (Zapus hudsonius).

○ June 9, Peninsula

Accipiter cooperi. CoOPER's HAwK.-Recorded only once during our entire survey. An adult was positively identified, on June 11 at Peninsula, as it flew over camp. This occurrence is slightly north of the normal summer range in Ontario. 
Buteo borealis. RED-TAILED HAWK.-Found regularly but rare at each camp. An adult male collected at Amyot on July 3, when dissected, was found to contain five newly-hatched Spruce Grouse, three in the crop and two in the stomach. They had been swallowed whole and were so little mutilated that one was skinned and preserved as a study specimen.

A comparison of the specimen with a series in the museum collection clearly showed it to be typical of the form borealis.

\section{$0^{7}$ July 3 , Amyot}

Buteo platypterus. BROAD-WINGED HAwk.-Present at each camp though not common. Three was the largest number recorded for one day.

Aquila chrysaetos. Golden F.agle.-One individual was positively identified on June 20 at Peninsula as it was flying overhead. The presence of this species at such a late date suggests that it may breed rarely in the region. The little-frequented rocky islands and the precipitous shores along Lake Superior should prove to be suitable for their nesting requirements.

The literature contains an old record of a pair nesting at Thunder Cape to the west of our area (Raine, 1892).

Haliaeetus leucocephalus. BALD EAGLE.-Recorded on two occasions, both at Rossport. Certainly a rare summer resident of the region as a whole.

Circus hudsonius. MARsh HAwk.-A rare summer resident. Although observed at each of our camps, two was the greatest number seen on one day. On June 18 at Peninsula an adult male was observed performing its courtship flight.

Pandion haliaetus. Osprey.-Seen occasionally at all three camps. Apparently a rare summer resident of the region as a whole.

Falco peregrinus. Peregrine Falcon.-Met with only once, at Peninsula on June 21. During a cruise about the rocky islands a mile or so off shore, three individuals were observed at sites where apparently ideal conditions for nesting prevailed. While visiting a small colony of Herring Gulls on Blondin Island, off Peninsula, two Peregrine Falcons, probably a mated pair, joined the gulls in protesting the human intrusion. A nest along the rocky cliffs of the island was suspected but a careful scrutiny next day revealed no eyrie or any sign of the birds. Joseph Douglas of Rossport, however, found a nest with two large young on a rock-ledge 40 feet above the water on Cobinosh Island, eight miles out in the lake from that place, in July, 1935. The young were identified by Col. L. S. Dear, in 1936, in the Fort William Zoo where they had been forwarded as exhibits. 
Falco columbarius. Pigeon Hawk.-A rare summer resident met with occasionally at each camp. At Amyot the agitated actions of a pair in a certain patch of spruces when we approached suggested the presence of young but no positive evidence was secured. No specimens were collected.

On May 27 at Rossport one was seen to make an unsuccessful attempt to catch a Barn Swallow in flight.

Falco sparverius. American Sparrow Hawk.-The commonest hawk at Rossport and Peninsula but strangely ennugh not recorded at Amyot. In Inever, it occurs at least sparingly inland since an individual was seen from the train un July 7 near Grasset, a short distance east of Amyot, and Mr. Green noted it in June, 1924, at Franz. At Rossport on May 29 a female and a set of five fresh eggs were collected. The nest was situated in an old Flicker hole five feet up in a telegraph pole.

$$
\text { 이 29, Rossport ơ June 12, Peninsula }
$$

Canachites canadensis. SPruce Grouse.-We met with this species only at Amyot where four families (including five young in the Red-tailed Hawk crop and stomach) were recorded between June 29 and July 4. During this period young were all quite small, apparently not long hatched, but capable of flight up to about twenty yards.

Thompson (1887) records the species as plentiful near Schreiber. Mr. Green found this grouse to be common at Franz in June, 1924.

Specimens are referable to the form canadensis.

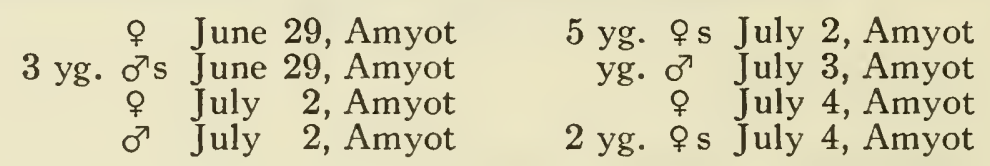

Bonasa umbellus. Ruffed Grouse--Rather uncommon at the time of our visit to the region. At Rossport they were a little more in evidence than at the other two camps. A female and brood of newlyhatched young were noted on June 27 at Amyot. A female collected from a paper birch sapling at Rossport on June 1 had its crop full of birch leaves. Dissection of the specimen also revealed five eggs, one almost ready to be laid.

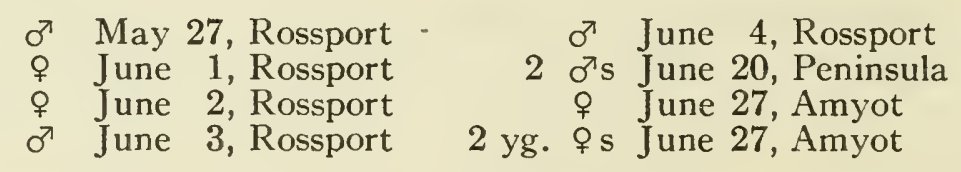

Fulica americana. American Coot.-Morris M. Green lists this species among the birds he saw at Franz in June, 1924. We made no observation which would contribute more knowledge as to the status of the species in this region. 
Charadrius semipalmatus. Semipalmated Plover.-Our only record, a male taken on June 1 , at Rossport, undoubtedly concerned a migrant.

\section{$\sigma^{7}$ June 1, Rossport}

Oxyechus vociferus. Killdeer Plover,-An uncommon summer resident of the region due to the restriction of suitable habitat. Not recorded by us at Amyot. On June 21 at Peninsula four newly-hatched young were secured from a nest.

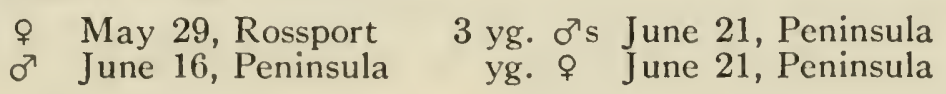

Squatarola squatarola. Black-BELlied Plover.-The only occurrence recorded by us was a female collected on May 29 at Rossport. This bird was undoubtedly a migrant. It is in winter plumage with traces of the breeding plumage coming in on the throat, upper breast and back.

\section{\& May 29, Rossport}

Capella delicata. WiLson's SniPE.--One was flushed from a grassy marsh at the edge of a black spruce bog on June 13 at Peninsula. This species is probably a rare summer resident where suitable habitat exists. At Franz it was noted in June, 1924, by Mr. Green.

Actitis macularia. Spotted Sandpiper.-Not a common bird; a few were noted at each camp. At Amyot a nest containing four eggs on the point of hatching was found on June 27 . On July 4 a brood of four newly-hatched young was observed.

A male taken on June 25 is of interest. It is in normal spotted breeding plumage with the exception of a patch on the left upper breast which is fresh unspotted plumage, many of the feathers still in sheaths. A careful examination of the rest of the plumage reveals no sign of moult. The only explanation is that this is a replace of plumage lost, possibly by accident.

$\begin{array}{lll}\sigma^{7} & \text { June } 16, \text { Peninsula } & \text { yg. कs July } 4 \text {, Amyot } \\ \$ & \text { June 25, Amyot } & \text { yg. ? J July } 4 \text {, Amyot } \\ 9 & \text { July } 3 \text {, Amyot } & \text { o July } 4 \text {, Amyot }\end{array}$

Ereunetes pusillus. Semipalmated Sandpiper:-Two individuals observed on May 29 at Rossport were undoubtedly migrants.

$$
\sigma^{7} \text { May 29, Rossport }
$$

Larus argentatus. HERRING Gull.-The only gull found in the region by us during the summer. Along Lake Superior they were present in fairly large numbers. At Rossport from fifty to two hundred were noted daily while at Peninsula from two to fifty were recorded. At Amyot seven was the largest number seen in one day. 
The species was found breeding on Kingcome Island off Rossport where a single nest was found on June 1 with three half-incubated eggs. At Peninsula a colony of about ten pairs was found on Blondin Island on June 21, nesting on rock ledges some ten feet above the water at the base of the cliffs. At this date the young birds were hatched and many of them sought to escape by hiding in crevices. Four were collected, two of which were quite small, clothed entirely with down; the other two were somewhat older with a considerable growth of juvenile feathers on the wings, back, sides of breast and tail.

$$
\begin{gathered}
\$ \text { yg. June } \\
\sigma^{7} \mathrm{~s} \text { June } 21 \text {, Rossport Peninsula } 2 \text { yg. } \text { o }^{7} \mathrm{~s} \text { June 22, Peninsula } \\
\sigma^{7} \text { June 26, Amyot }
\end{gathered}
$$

Sterna hirundo. Common TERN.-A flock of six seen on May 30 at Rossport established our only record for the species in the region surveyed.

Bubo virginianus. Great Horned Owl.-Recorded only at Amyot where we heard them on several nights. No specimens were secured and no satisfactory views were had of them. This was unfortunate inasmuch as the racial identity of this owl in this area is problematical. The A.O.U. Check-List (1931) attributes the typical form to this region. However, breast, back and neck feathers of a Great Horned Owl found in the nest of a Tree Swallow at Amyot on June 25 are clearly referable to the race subarcticus and were matched on R.O.M.Z. June specimens from Ingolf and Wabigoon in southern Kenora district. The possibility exists, however, that the feathers used by the Tree Swallows were from wintering owls.

Surnia ulula. HAwK OwL.-Probably a rare summer resident of the region where suitable habitat occurs. We met with it only on one occasion, June 12, at Peninsula. The bird, a male, was secured in a large tract of standing dead trees which had been swept by fire the previous year.

\section{$\sigma^{7}$ June 12 , Peninsula}

Strix varia. BARRED OWL.-The occurrence of this species in the region during the summer is based on a single fresh feather picked up in a large mixed woods on June 27 at Amyot.

\section{feather, June 27, Amyot}

Chordeiles minor. Nightнawk.-Seen regularly at all camps but by no means commonly. No breeding evidence was secured, but they nest, no doubt, in the region since extensive suitable habitat exists.

$$
\text { ㅇ June } 3 \text {, Rossport } \quad \text { June } 15 \text {, Peninsula }
$$


Chaetura pelagica. Chimney Swift.-Occasionally seen at Rossport and Peninsula; not recorded at Amyot. We did not find them breeding. One was seen on May 26 at White River.

\section{or June 10, Peninsula}

Archilochus colubris. RuBy-THROATED HummingBIRD.-A rare summer resident of the region, recorded by us on a few occasions at Rossport and Peninsula. No positive breeding evidence was secured though a male was seen performing its curious pendulum courtship flight on June 4 .

Megaceryle alcyon. Belted Kingfisher.-A not uncommon summer resident at all three camps. On May 31 at Rossport two nests were opened up and the contents of each collected. One contained seven fresh eggs on which the male was sitting; the other, four fresh eggs, probably an incomplete set. Both nesting chambers were but three feet in from the face of the bank. While digging down to the nests, frost was encountered at a depth of two feet; the chambers were surrounded by frozen sand. This probably accounts for the shortness of the tunnels.

On July 2 at Amyot a nest was opened up which contained seven young, several days old. The length of the tunnel to this nest was the usual six to seven feet.

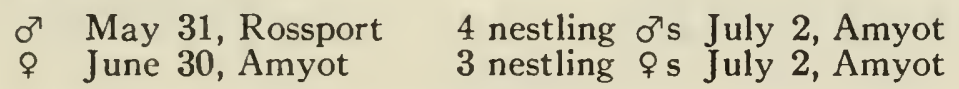

Colaptes auratus. Yellow-Shafted Flicker.-The commonest woodpecker of the region found nesting in several types of habitat and at all camps. Telegraph poles along the railroad right-of-way were nesting sites especially attractive to the species. On May 30, at Rossport, a male was captured from such a situation, as it was busy excavating the nesting chamber. At Amyot, on June 23, a nest four feet up in a fence post, contained six young several days old and an addled egg. A nest at the same camp, found on June 27 , three feet up in a dead stub of birch, contained seven heavily incubated eggs.

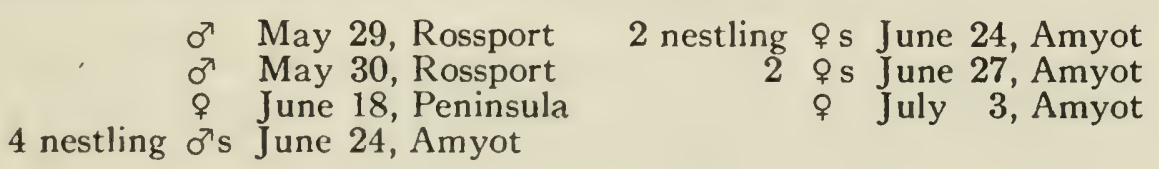

Ceophloeus pileatus. Pileated Woodpecker.-Recorded on but one occasion, July 4, at Amyot. It is apparently found sparingly throughout the region as a whole, as their workings were noted occasionally at all three camps. 
Melanerpes erythrocephalus. Red-headed Woodpecker.-Our only record was an individual observed by Mr. Downing on June 19 at Peninsula. This is undoubtedly near the northern limits of its range on this longitude.

Sphyrapicus varius. Yellow-Bellied SaPsucker.-A surprising fact was the almost total absence of this species in the region under consideration. Our only records were at Amyot in late June and early July. From one to three individuals were seen there on four different days. On June 27 a nesting hole was found thirty-five feet up in a living poplar. Contents of the nest were not ascertained.

\section{$\sigma^{7}$ June 27, Amyot}

Dryobates villosus. HaIRy WoODPecker.-Like the sapsucker, this species was almost totally absent from the general region. We only met with it on three days at Amyot. An adult male and two juveniles of the same sex were secured. The mature bird is somewhat intermediate between villosus and septentrionalis. The length of the culmen, $33 \mathrm{~mm}$., is within the range of septentrionalis but the shortness of the wing, 123 $\mathrm{mm}$., falls within the range given for villosus. It was among the species listed for Franz by Mr. Green in June, 1924 (one individual).

$$
\text { Juv. } \sigma^{7} \text { June 30, Amyot } 30 \text {, Amyot } \quad \text { Juv. } \sigma^{7} \text { July 3, Amyot }
$$

Dryobates pubescens. Downy WoodPECKer.-Not uncommon at all three camps. At Rossport on June 1, a newly-excavated nest was found twenty feet up in a dead poplar stub. On June 17 at Peninsula, a nest eight feet up in a dead stub was found which contained two fresh eggs. At Amyot on June 25, at dusk, a nest was found twelve feet up in a dead birch stub. The stub was tapped and a male flew off and was collected. The set consisted of three partially incubated eggs and was collected along with the section of stub containing the nesting chamber. The following measurements were taken of the nesting cavity: depth, $6 \frac{5}{8}{ }^{\prime \prime}$; diameter, $3^{\prime \prime}$; diameter of entrance, $1 \frac{1}{4}^{\prime \prime}$.

The series collected are closer in measurements to nelsoni than to medianus. The white, both ventrally and dorsally, is purer when compared with specimens from the southern part of Ontario.

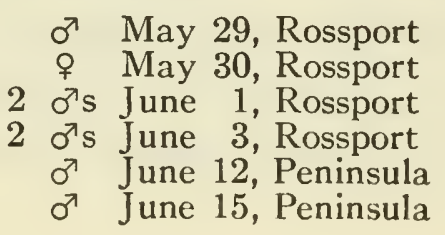

2 ㅇ s June 15, Peninsula o June 18, Peninsula

2 ots June 20, Peninsula ot June 25, Amyot o July 3, Amyot 
Picoides arcticus. Arctic Three-toed Woodpecker.-This species was only met with at Peninsula where it was rare. At Pic on July 13, 1848, Cabot noted it as "abundant", feeding on wood-boring beetles (Agassiz, 1850).

ㄱ June 10, Peninsula

Picoides tridactylus. American Three-toed Woodpecker This species was noted on July 13, 1848, at Pic by J. E. Cabot (Agassiz, 1850).

Tyrannus tyrannus. EAstern KingBird.-A rare summer resident at all three camps; the largest number we recorded on a single day was two. No breeding, evidence was secured.

$0^{x}$ June 13 , Peninsula

ㅇ. June 26, Amyot

Sayornis phoebe. EAstern Phoebe.-A rare summer resident throughout the region under consideration. At Amyot a used nest was found on June 23, situated under the eaves of one of the railway buildings. Mr. Green observed a pair at Franz in June, 1924, and it was listed at Pic by Cabot in 1848 (Agassiz, 1850).

$\sigma^{7}$ June 3, Rossport o June 30, Amyot

Empidonax flaviventris. Yellow-Bellied Flycatcher.-A not uncommon summer resident at all three camps, found most frequently in the black spruce bogs. No actual breeding evidence was secured though a pair seen on June 19 at Peninsula in typical habitat acted very agitated when a certain spot in the spruce bog was approached.

2 is June 2, Rossport \& June 6, Rossport

\section{\% June 10, Peninsula}

ơ July 3, Amyot

Empidonax trailli. Traill's Flycatcher.-A very common summer resident throughout the area investigated. It was found to prefer moist, dense growths of alders and willows. Though considerable time was spent searching for nests in such places, no actual breeding evidence was obtained.

At Rossport the first Traill's Flycatcher was noted on May 30. On June 1 , six were recorded and from then on they were present in fairly large numbers.

$3 \sigma^{T}$ s June 1, Rossport

$\sigma^{7}$ June 2, Rossport

$0^{7}$ June 5, Rossport

$0^{7}$ June 6, Rossport

\& June 10, Peninsula

$\sigma^{7}$ June 12, Peninsula

$\sigma^{7}$ June 20, Peninsula

\& June 20, Peninsula 
Empidonax minimus. LEAST Flycatcher.-A very common breeding bird at all three camps. Unlike the previous species it was not confined to one particular type of habitat. Though displaying wide adaptability they appeared to be most numerous in the scrubby growth of recent burns. In such a place at Peninsula, on June 18, three nests were found, their location ranging from 3 feet, 6 inches to 8 feet off the ground in small, dead trees. Two were newly built while the third contained one egg. On June 21, the same area was visited and four additional nests were found, all 3 to 10 feet up in dead trees. At Amyot on June 26, a nest containing three half-incubated eggs was found 4 feet from the ground in the fork of a small white birch.
$\sigma^{7}$ June 3, Rossport
I June 11, Peninsula
$\sigma^{7}$ June 13, Peninsula
$\sigma^{7}$ June 18, Peninsula

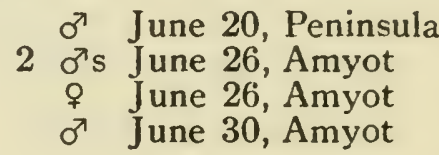

Nuttallornis mesoleucus. Olive-sided Flycatcher.-The familiar call note of this species was heard frequently at all three camps. At Peninsula, where a number of burns are present with standing dead timber, as many as eleven individuals were recorded for one day. At this place a nest was collected on June 21 containing three fresh eggs. It was situated 30 feet up on a branch of a leaning dead spruce. Both birds were quite active in defence of the nest and would make frequent dives at the human intruder.

$$
\sigma^{7} \text { June 11, Peninsula } \quad \text { June 11, Peninsula }
$$

Otocoris alpestris. HORNED LARK.- Rare in the region under consideration. Noted on but one or two occasions at each camp. Suitable habitat does not exist extensively in the region.

The males are referable to the form praticola but the female specimen is clearly alpestris.

$$
\begin{array}{lll}
\sigma^{7} & \text { May 29, Rossport } \\
\$ & \text { May 29, Rossport }
\end{array} \quad \text { o June 17, Peninsula }
$$

Iridoprocne bicolor. TREE Swallow.-A common summer resident in all three areas worked, particularly at Rossport where as many as thirty individuals were recorded daily. At Peninsula they frequented standing dead trees in areas recently burned over. In such places they found ideal nesting sites in old woodpecker holes.

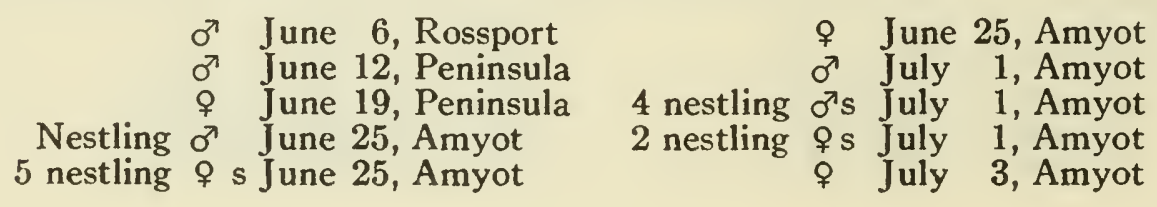


Hirundo erythrogaster. BARN Swallow.-Recorded only at Rossport where from ten to thirty were seen daily about the village. On June 1 we found two newly-built nests in an old boat-house. On June 4 a nest containing five fresh eggs was secured from a rafter in an ice-house. At Franz, a pair was noted in June, 1924, by Mr. Green. Cabot (Agassiz, 1850) records Barn Swallows' nests "niched into the rock within reach of the hand" near Schreiber on July 16, 1848.

\& June 5, Rossport

Petrochelidon albifrons. Cliff Swallow.-Our only record was the occurrence on May 27 at Rossport of an individual seen with the Barn Swallows.

Perisoreus canadensis. CANADA JAY.- Noted sparingly at each camp where family groups, usually consisting of two adults and two fully-grown juveniles, were met with. They showed little evidence of fear of humans, coming within a few feet of us on occasions.

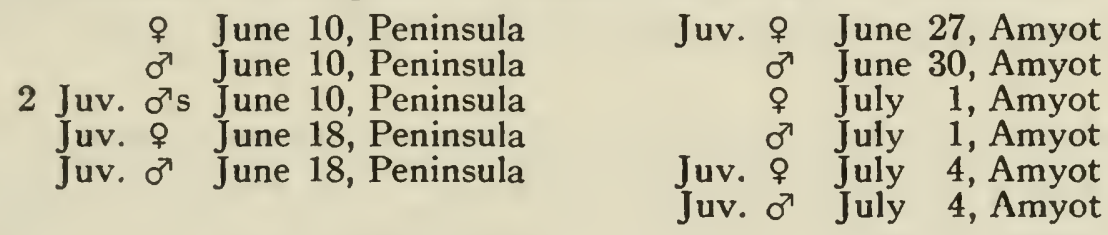

Cyanocitta cristata. BLUE JAY.-Recorded only at Rossport where it was not uncommon. One observed on May 28, uttered a perfect imitation of the Broad-winged Hawk's "cut-eee" note. This observation supports the belief that the species is a hawk mimic. In the south it frequently gives a cry like that of the Red-shouldered Hawk.

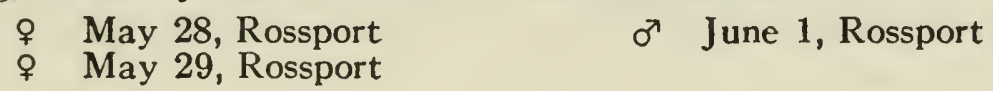

Corvus corax. RAven.- - Recorded on a few occasions at each camp. At Rossport on June 3, one was seen being harassed by a crow. The disparity in size was very evident on this occasion. Twice at Amyot a group of four and a group of five, respectively, were seen near camp, possibly family groups.

No specimens were secured.

Corvus brachyrhynchos. AMERICAN CRow.-A fairly common bird throughout the area under consideration. At Rossport, on May 27, a nest, found by Mr. Downing, was discovered twenty feet up in a white spruce. It contained five small naked young. At Amyot a juvenile not long out of the nest was taken on July 1.

Nestling \& May 27, Rossport

o June 27, Amyot $\begin{array}{rrr}\sigma^{x} & \text { June } & 30, \text { Amyot } \\ \text { Juv. } \sigma^{x} & \text { July } & 1 \text {, Amyot }\end{array}$ 
Penthestes atricapillus. Black-Capped Chickadee.-A fairly common species throughout the area surveyed. On June 20 at Peninsula, six nestlings not more than two or three days old were secured from a nest in a cavity in a dead birch stub twelve feet up.

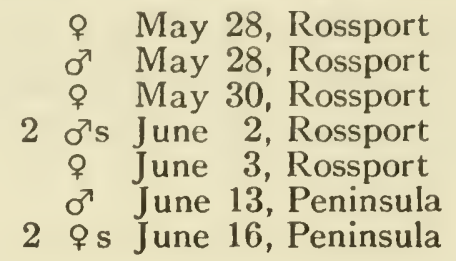

2 nestling $\sigma^{7}$ June 16 , Peninsula
4 nestling 20 , Peninsula
कs June 20, Peninsula
$\sigma^{7}$ June 20, Peninsula
\& June 20, Peninsula
$\sigma^{7}$ June 29, Amyot
$\sigma^{7}$ July 4, Amyot

Penthestes hudsonicus. Brown-Headed Chickadee.-This species was recorded at each camp but not nearly as frequently as the preceding one. They were found chiefly in or near black spruce bogs. At Peninsula two nests were found in this type of habitat, one on June 12 and one on June 13. Both were in cavities in decaying black spruce stubs, six and eight feet up respectively. Each contained six heavilyincubated eggs and in both cases the incubating adult was the female. The nests were a mat of closely packed fur, mainly that of the Varying Hare.

At Amyot on July 1, a nest of this species was found in an old woodpecker's hole in a dead jackpine five feet up. The habitat in this case was an open park-like stand of jackpine but adjacent to a fairly extensive black spruce bog. The nest contained four fully-fledged juveniles almost ready for flight. As in the case of the two nests mentioned above, it was the female which was in attendance at the nest.

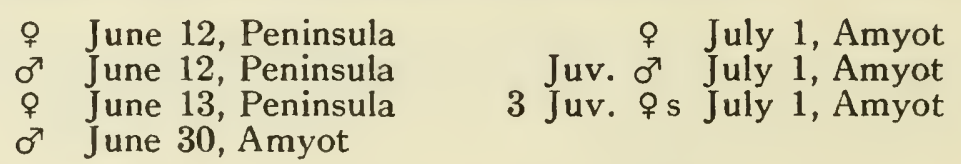

Sitta canadensis. ReD-BREASted Nuthatch.-Noted sparingly throughout the area under discussion. No specimens were collected.

At Amyot on June 27, a breeding record was established when an adult was watched as it fed a juvenile not long out of the nest.

Certhia familiaris. Brown CReEper.-Noted on but one occasion, namely, June 13 at Peninsula, where a pair and nest were secured. The nest was a beautiful structure situated seven feet from the ground behind a slab of loosely-hanging bark of a dead white spruce. It contained five slightly-incubated eggs.
$\sigma^{7}$ June 13 , Peninsula
o June 13 , Peninsula

Troglodytes aedon. House Wren.-Noted as not uncommon at Rossport and Peninsula, but not recorded at Amyot. At Peninsula they 
were found established in a wet border of a black spruce bog where there were a good number of standing birch stubs. In one of the stubs a partially constructed nest was found.

The specimens collected are referable to the form, parkmani.
o May 30, Rossport
o June 5, Rossport
2 o's June 11, Peninsula
2 ors June 15, Peninsula
\& June 18, Peninsula
$0^{7}$ June 18, Peninsula

Nannus hiemalis. Winter WREN.-A rare species at all three camps. A female taken on June 3 at Rossport possessed the bare incubation patch on the belly. At Peninsula on June 12, a partially constructed nest was found under the roots of a fallen tree.
\& June 3, Rossport
\& June 12, Peninsula

Turdus migratorius. American Robin.-Fairly common at Rossport and Amyot, rather scarce at Peninsula. At the time of our arrival robins were just commencing to lay. On May 30 at Rossport, a nest containing two fresh eggs was found ten feet up in a balsam fir. Also on the same date a nest containing four fresh eggs was found, seven feet up on a horizontal branch of a white spruce. At Peninsula on June 18, a nest containing three small young and one egg was collected. A nest containing three small young was collected on July 4 at Amyot.

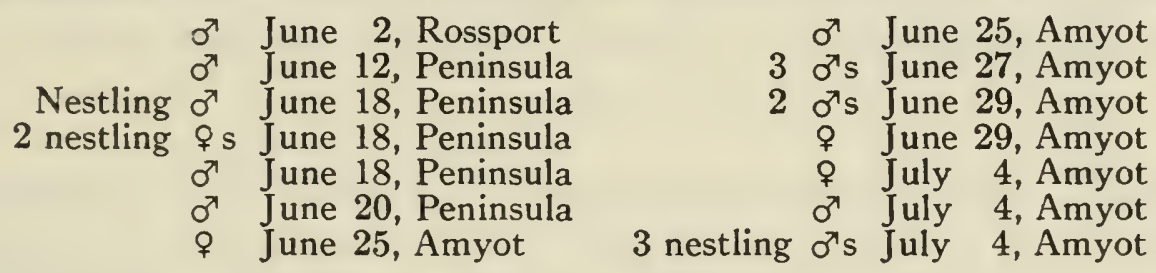

Hylocichla guttata. Hermit Thrush.-Fairly common throughout the area under discussion. At Peninsula we were afforded many opportunities of listening to this species sing. On a quiet evening males could be heard from all directions as they sang from their stations at the top of distant spruces. Surely they are the finest songsters of the north. A nest found at this camp on June 18 contained three newly-hatched young. It was situated on the ground under a small white spruce in a dry situation. On July 3 at Amyot, a juvenile not long out of the nest was collected.

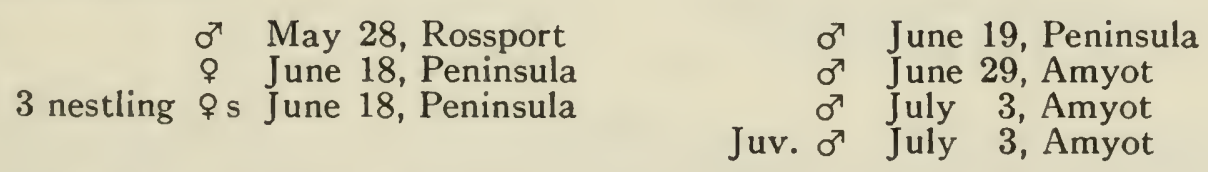

Hylocichla ustulata. Olrve-BACKed Thrush.-The commonest thrush of the region. Particularly plentiful at Amyot where as many as thirty-three were recorded on one day. On June 20, at Peninsula, a 
partially constructed nest was found in a tiny white spruce one foot above the ground. On June 25 at Amyot, a nest, on which the bird was sitting, was found twenty-five feet up in a jackpine. At the same camp on July 2, a nest which contained three newly-hatched young and one infertile egg was found situated five feet up in a small balsam fir. At Franz, Mr. Green found a nest with two eggs on June 24, 1924.

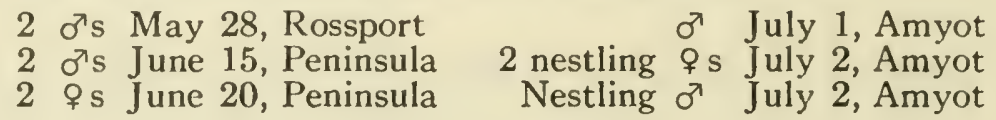

Hylocichla minima. GREY-CheEked Thrush,--Our only record for this northern species was of a female taken in a mouse trap at Rossport on May 31. It was undoubtedly a belated migrant.

\& May 31, Rossport

Hylocichla fuscescens. WiLson's ThRUSH.-A single specimen taken at Rossport on June 4 constitutes our only record of occurrence for the region. This area probably marks the northern limits of range of this species in Ontario.

The specimen secured, when compared with material from various parts of the province, is referable to the sub-species, salicicola.

Cabot (Agassiz, 1850) lists Turdus brunneus for Pic in the summer of 1848. This apparently refers to Wilson's Thrush (Ridgway, 1907).

\section{o June 4, Rossport}

Sialia sialis. RED-BREASTEd BluEBIRD.-Rather scarce at Rossport and Peninsula; not recorded for Amyot. At Peninsula they were found inhabiting a burn in which dead trees and stubs still remained standing.

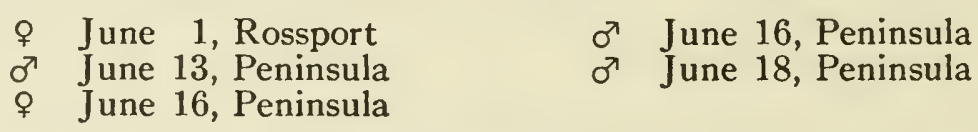

Regulus satrapa. GoLden-CROwnEd Kinglet.-Recorded not uncommonly from all three camps. A habitat preference for mixed woods which contain a fair percentage of white spruce and balsam fir was evident. Dissection of a female taken on June 10 at Peninsula disclosed a well-developed egg which had entered the oviduct.

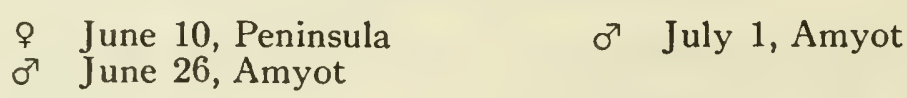

Corthylio calendula. Ruby-Crowned Kinglet.-Not uncommon throughout the general region, found particularly in dense black spruce stands. On June 18 at Peninsula, in a wet swale, at the edge of a burn overgrown with black spruce, white spruce, paper birch and alders, a nest was found ten feet up in a small white spruce. It contained nine 
eggs. Eight were on the point of hatching while the remaining one was sterile. We were first attracted to the section where the nest was found by the singing of the male. The bird was discovered with what appeared to be nesting material in its beak which it carried to and deposited in the small white spruce. Investigation revealed the nest which was a beautiful structure of moss, lined with feathers of several species of birds, among which those of the Ruffed Grouse were identified.
2 o's June 12, Peninsula
$\sigma^{7}$ June 24, Amyot

Anthus spinoletta. AMERICAN PIPIT.-The only occurrences for the general region were one collected on May 27 at Rossport, and two noted at the same place on May 29. No doubt these birds were late migrants passing through.

\& May 27, Rossport

Bombycilla cedrorum. CEDAR WAXWING.-A common bird throughout the area surveyed. It did not put in an appearance at Rossport till June 1. From then on for a month, Cedar Waxwings were recorded regularly in flocks of varying sizes. On June 6, one flock was seen which contained an estimated one hundred or more individuals. Pairs segregated for nesting in early July.

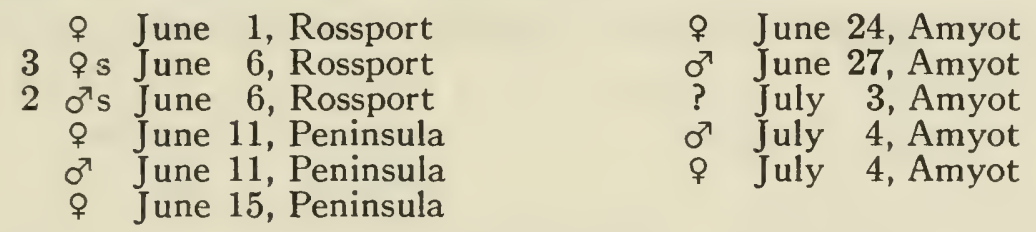

Sturnus rulgaris. Common Starling.-A few were noted at Rossport and Amyot, mainly in the vicinity of human habitation. At Peninsula only one individual was recorded. It was flushed from a nest, ten feet up in a dead stub, which contained two heavily incubated eggs. This nest was in a burn some distance from the settlement at Peninsula. A nest found at Rossport on June 4 was situated in an old Flicker hole five feet up in a telegraph pole along the railroad right-of-way. It contained four fresh eggs, perhaps not a complete set. At Amyot two nests, both containing young, were discovered on June 23. One, located in a hole in a fence post, contained five fully-fledged young capable of strong flight. The other, situated five feet up in a hole in an aspen, stub, contained three partially feathered young.

We found adults of the species consistently wary and difficult of approach.

Juv. or June 23, Amyot

3 Juv. is June 23, Amyot
Nestling or June 23, Amyot

2 nestling of June 23, Amyot 
Vireo solitarius. Soldtary Vireo.-Recorded on a few occasions at Rossport and Amyot. Not found by us at Peninsula. At Amyot a breeding record was established on July 4 , when a juvenile, not long out of the nest and capable of very little flight, was secured.

$$
\begin{aligned}
& \text { o June 29, Amyot } \\
& \text { क July } 3 \text {, Amyot }
\end{aligned}
$$

Vireo olivaceus. RED-EYED VIREO.-Noted commonly throughout the general region, particularly so at Amyot where as many as thirty individuals were recorded for one day.

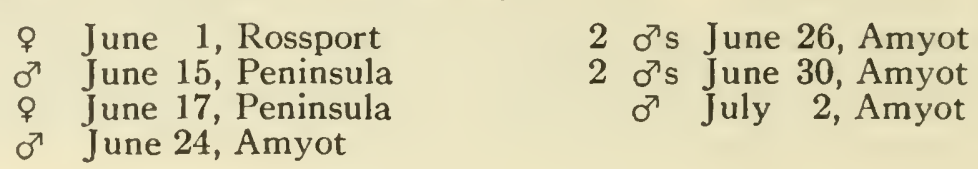

Vireo philadelphicus. Philadelphia Vireo.-Recorded at each camp but not as numerously as the preceding species. They were found to prefer moist alder patches as habitat rather than the drier poplar and birch woods.

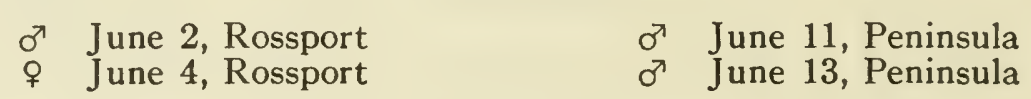

Mniotilta varia. Black AND White WARBLER.-Noted as rather uncommon throughout the area under consideration. No breeding evidence was secured.

$$
\sigma^{7} \text { June 2, Rossport o June 27, Amyot }
$$

Vermivora peregrina. Tennessee WARBLER.-A rare summer bird in the area. Seen several times at Rossport in early June during which period late migrants may have been still in the region. Not recorded at Peninsula and seen but once at Amyot, on June 26. Cabot Agassiz, 1850) records this species at Pic with young in July, 1848.

$$
\sigma^{7} \text { June 1, Rossport } \quad \text { June 2, Rossport }
$$

Vermivora ruficapilla. NASHVILLE WARBLER.-Recorded as a fairly common bird at each of our camps. We found it in a variety of habitat situations. In a large black spruce bog at Peninsula, on June 13, thirty-five were noted.

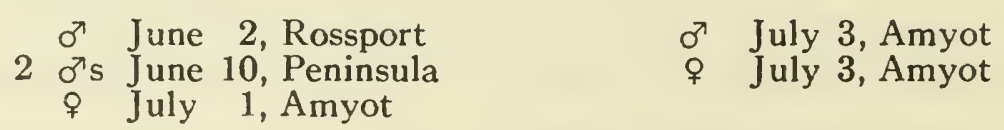

Compsothlypis americana. PARULA WARBLER.-Our only record is of a female taken at Rossport on June 6. A gross examination of the ovaries did not suggest that this bird was in a breeding condition. 
Dendroica aestiva. Yellow Warbler.-Rather common at Rossport and Amyot; not observed at Peninsula. At Rossport a partially constructed nest was found on June 7 .

A comparison of the series obtained, with specimens from throughout southern Ontario, shows some obvious differences, most marked in the females. The under parts of the three females secured are paler with less yellow. The upper parts are less vivid green, more olivaceous. No appreciable difference is obvious on the under parts of males. Their upper parts, in series, tend to be less green, inclining toward olivaceous.

Comparison of specimens from a wider geographic area discloses that the characters observed in the Rossport and Amyot birds are evident in Ontario specimens from north of Lake Nipissing and the French River. Though suggestive of the existence of two races in the province, material at hand is insufficient for complete study. No doubt, the matter extends beyond provincial limits. As has been said, differentiation is most noticeable in females, which are comparatively rare in collections.

\begin{tabular}{|c|c|c|c|}
\hline$\sigma^{7}$ & May 28, Rossport & ㅇ & 6, Rossport \\
\hline$\sigma^{\top} \mathrm{s}$ & May 29, Rossport & $\sigma^{7}$ & 6. Rossport \\
\hline$\sigma^{7} s$ & May 30 , Rossport & $\sigma^{7}$ & June 26, Amyot \\
\hline 오 & June 1 , Rossport & $\sigma^{7}$ & June 27, Amyot \\
\hline$\sigma^{7} s$ & June 1 , Rossport & & \\
\hline
\end{tabular}

Dendroica magnolia. Magnolia W,ARBLER.-A not uncommon warbler throughout the region. They were found mostly in mixed woods, particularly where small white spruce existed.
o June 2, Rossport
2 o's June 10, Peninsula
$\sigma^{7}$ July 3 , Amyot

Dendroica coronata. Myrtle WA RBLER.-Not uncommon at all three camps. A nest found at Rossport on June 7, some twelve feet up in a white spruce, contained four fresh eggs.

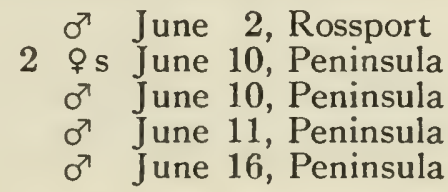

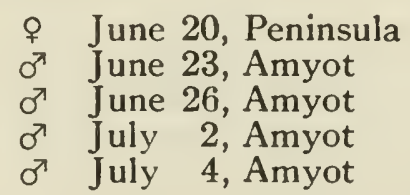

Dendroica virens. Black-throated Green Warbler.-Not uncommon at Rossport and Peninsula. Rather rare at Amyot. No definite breeding evidence was secured.
ơ June 5, Rossport
万' June 10, Peninsula
을 12 , Peninsula

Dendroica fusca. BlaCkBURNIAN WARBLER.-This brilliantlymarked species was quite rare throughout the area worked. It was recorded on but one or two occasions at each camp. On these occasions they were found in large mature mixed woods. 
Dendroica pensylvanica. Chestnut-sided Warbler.-Present at each camp but not a common species. They were found to inhabitalders and small second-growth.

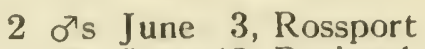
$\sigma^{7}$ June 13 , Peninsula
$0^{7}$ July 3, Amyot

Dendroica castanea. BAY-BREASTED Warbler.-Found only at Amyot where it inhabited mainly the more mature mixed forest. Despite the presence of singing males, diligent searching of the habitats they frequented did not disclose females or nests.
$\sigma^{7}$ June 26, Amyot
$\sigma^{7}$ June 28, Amyot
$\sigma^{7}$ June 29, Amyot
$0^{7}$
$0^{7}$

Seiurus aurocapillus. OvEn-BIRD. Rather uncommon when compared with the abundance of this species in other parts of the province. We found they preferred the drier woods where poplar and birch predominated.
$\sigma^{7}$ June 5, Rossport
$\sigma^{7}$ June 24, Amyot
$\sigma^{7}$ June 16, Peninsula
June 26, Amyot

Seiurus noveboracensis. NORTHER WATER-THRUSH.-Quite scarce throughout the region as a whole. No breeding data were secured.
i June 4, Rossport
$\sigma^{\top}$ July 3, Amyot

Oporornis agilis. Connecticut WARBLer.- Noted only at Amyot where a few singing males were encountered in spruce bogs. They sang from near the tops of spruce trees, usually in early morning. Despite frequent trips through these bogs no signs of females or breeding evidence was obtained.

$\sigma^{7}$ June 30 , Amyot

$\sigma^{2}$ July 1 , Amyot

Oporornis philadelphia. Mourning Warbler.-Not uncommon at all three camps where they were found to frequent the new growth in recent burns and clearings.

$$
\begin{array}{cc}
\sigma^{7} & \text { June 3, Rossport } \\
\sigma^{7} & \text { June 4, Rossport } \\
\sigma^{7} & \text { June 5, Rossport } \\
2 & \sigma^{7} \text { June 6, Rossport }
\end{array}
$$

$\sigma^{7}$ June 13 , Peninsula

o June 18, Peninsula

$0^{7}$ June 19, Peninsula

$0^{7}$ June 27, Amyot

Geothlypis trichas. Maryland Yellow-throat.-Surprisingly scarce in the region worked. The only occurrence for Rossport was a female taken in a mouse trap on May 31. We did not record it at Peninsula. At Amyot it was recorded but twice. One was heard singing at Franz on July 7.

o May 31, Rossport

$\sigma^{7}$ July 3, Amyot 
Wilsonia pusilla. BLACK-CAPPED WARBLER.-A few were noted between May 29 and June 1 at Rossport. Though these were frequenting wet alder growths, the type of habitat in which they breed, we are inclined to regard them as late migrants since none was noted after June 1.

$$
\text { ơ May 29, Rossport }
$$

Wilsonia canadensis. CANADA WARBLER.-Not uncommon in suitable habitat throughout the area worked. No evidence of breeding was obtained.

$2 \sigma^{7} s$ June 4, Rossport \& June 5, Rossport
$2 \sigma^{7} s$ June 15, Peninsula $\sigma^{7}$ July 1, Amyot

Setophaga ruticilla. AMERICAN RedstaRt.-The Redstart was a common summer resident in the area. At Peninsula a nest was found on June 11 (female was building); on the 21 st it contained one fresh egg. The nest was placed five feet from the ground in an alder.

2 o's June 2, Rossport
\% June 3, Rossport
o J June 13, Peninsula
$\$$ June 14, Peninsula

Passer domesticus. English SparRow.-Our only record of this species was obtained at Rossport where three were seen on May 30. Mr. Green noted it at Franz in June, 1924.

Agelaius phoeniceus. RED-WINGED BLACKBIRD.-This species was noted at Rossport, where one or two were seen occasionally between May 27 and June 5. A male was seen at White River on May 26.

\section{$\sigma^{7}$ May 30, Rossport}

Euphagus carolinus. Rusty BlACkBIRD.-The Rusty Blackbird was a rare summer resident of the area. One was seen at Rossport on May 30. A pair was established at Peninsula (nest with five young about a week old found on June 18, eighteen inches up in a small spruce). At Amyot it was noted at two places; one bird observed on June 26, and on June 27 a nest was found two feet, six inches up in a willow on the border of a small lake. Four young just out of the nest were in the nest vicinity.

The partially-feathered nestlings and fully-feathered flying juveniles collected exhibit a sexual difference in colour. The females are noticeably paler dorsally and ventrally, particularly dorsally.

Mr. Green saw a pair at Franz on June 28, 1924.

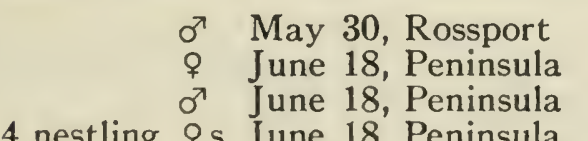

4 nestling $\& \mathrm{~s}$ June 18 , Peninsula
Nestling $\sigma^{7}$ June 18, Peninsula

2 Juv. 9 s June 27, Amyot

2 Juv. o's June 27, Amyot 
Quiscalus quiscula. Crow BlackBIRD.-This was a rare summer resident about the clearings at Rossport and Amyot; none seen at Peninsula. Three were the most seen on any one day.

At Amyot a nest with two well-feathered young was found on a beam in a barn on June 29.

$$
\begin{aligned}
& 0^{7} \text { June 25, Amyot Juv. \& June 29, Amyot } \\
& \text { \& June 29, Amyot Juv. } \sigma^{7} \text { June 29, Amyot }
\end{aligned}
$$

Molothrus ater. CowBIRD.-A few Cowbirds (up to three per day) were observed at Rossport. A male was noted at White River on May 26.
$\begin{array}{ll}\sigma^{7} & \text { May } 30, \text { Rossport } \\ \sigma^{7} & \text { June 1, Rossport }\end{array}$
ơ June 5, Rossport

Carpodacus purpureus. Common Purple Finch.-This was a common summer resident of the area, as many as twenty being seen on one day (July 4, Amyot).

$$
\begin{array}{ll}
\sigma^{7} & \text { June } 4, \text { Rossport } \\
\sigma^{7} & \text { June 6, Rossport } \\
\sigma^{7} & \text { June 12, Peninsula } \\
\sigma^{7} & \text { June 18, Peninsula } \\
\sigma^{7} & \text { June 20, Peninsula }
\end{array}
$$

Spinus pinus. Pine Siskin.-This was not an uncommon summer bird of the area; ten on June 10 (Peninsula) was the largest daily total. $\begin{array}{ll}\sigma^{7} & \text { June } 2, \text { Rossport } \\ \sigma^{7} & \text { June 4, Rossport }\end{array}$

$0^{7}$ June 15, Peninsula

Spinus tristis. American Goldfinch.-This goldfinch was distributed throughout the area, most commonly at Rossport, where as many as fourteen were seen on one day (June 4).

$$
0^{7} \text { June 1, Rossport o June 2, Rossport }
$$

Loxia leucoptera. White-Winged Crossbill.-Crossbills of undetermined species were seen on a few occasions at each of our three camps, but two seen (one collected) at Amyot were the only ones identified. They were of this species.

$$
\text { 이 July } 5 \text {, Amyot }
$$

Passerculus sandwichensis. Savannah Sparrow.-A common summer resident in the clearings at Rossport and Amyot. The only individual observed at Peninsula was frequenting an open grassy bog.

At Amyot a nest containing four young (several days old) was found on June 23 . On the 29 th and 30 th young out of the nest were observed.

The series of adults obtained is uniformly darker throughout than summer birds from southern Ontario. Savannah Sparrows from this area seem referable to oblitus (Peters and Griscom, 1938). 


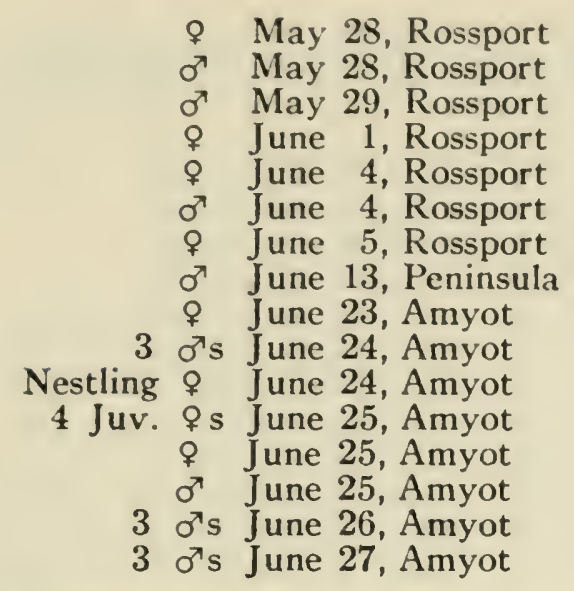

\% May 28, Rossport

or May 28, Rossport

o May 29, Rossport

or June 4, Rossport

\& June 5, Rossport

or June 13, Peninsula

3 o's June 24, Amyot

Nestling $\%$ June 24, Amyot

is June 25, Amyot

7 June 25, Amyot

3 o's June 27, Amyot

Pooecetes gramineus. Vesper SParrow.-Unlike the Savannah Sparrow, this species was quite common at Peninsula but comparatively scarce at Rossport and Amyot. At Peninsula there were large areas of dry, open country suitable to this species but there was an almost complete absence of grassy fields or clearings which might attract the Savannah Sparrow.

A nest, found on June 21 in dry open country, contained two eggs on the point of hatching.

The series of specimens obtained resembles closely gramineus, with the exception of the two specimens from Rossport which are slightly paler throughout, a characteristic of the western form confinis.

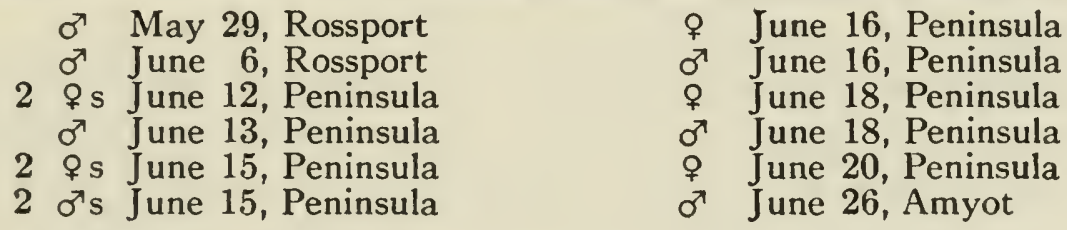

Junco hyemalis. Slate-COLOUREd JunCO.-This was a common species throughout the area visited.

A nest, found on June 18, at Peninsula, was on the ground under the lower branches of a tiny white spruce in the dry open plain. It contained five eggs. On June 29, at Amyot, another nest, in a similar situation, in. mixed forest, was found to contain four well-feathered nestlings.

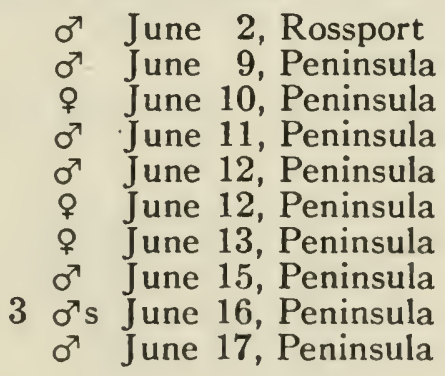

$$
\begin{aligned}
& \text { 을 17, Peninsula } \\
& 2 \text { क s June 18, Peninsula } \\
& \sigma^{7} \text { June 18, Peninsula } \\
& \text { o June 25, Amyot } \\
& \text { 우 June 27, Amyot } \\
& \text { or June 27, Amyot } \\
& 4 \text { nestling } \sigma^{7} \mathrm{~s} \text { June 29, Amyot } \\
& \text { ㅇ June 29, Amyot } \\
& \sigma^{7} \text { June 30, Amyot } \\
& 2 \text { ơ July 3, Amyot } \\
& \text { Juv. वे July 4, Amyot }
\end{aligned}
$$

Spizella passerina. ChIPPING SPARRow.-This was a common nesting bird of the area. Two nests found at Peninsula each contained four fresh eggs, on June 17 and 20 respectively. 
The form occurring in the region is passerina but the series of specimens collected is variable, about one-third are paler than specimens from southern Ontario.

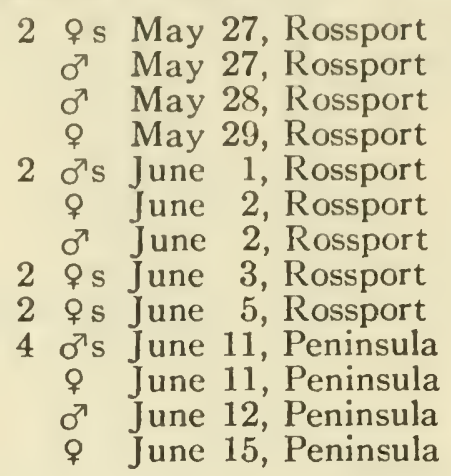

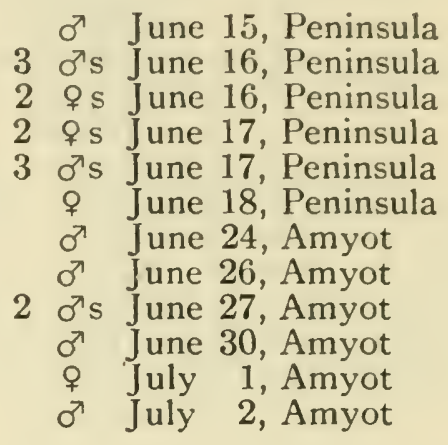

Spizella pallida. Clay-Coloured Sparrow.-Our only records of this species were made at Rossport, where two individuals (or the same one twice) were heard singing on May 27 and June 4.

Zonotrichia leucophrys. White-Crowned Sparrow.-At Rossport we recorded this species at the close of the spring migration; one seen on May 27 and a female collected on May 30. The latter is typical leucophrys.

\section{i May 30, Rossport}

Zonotrichia albicollis. WhITE-THROATEd SPARROW.-The Whitethroated Sparrow was an abundant breeding bird of the area.

A nest with four eggs, about half-way through the incubation period, was found on a small island off Rossport on June 7 . On June 27, at Amyot, a nest with four young a few days old was collected.

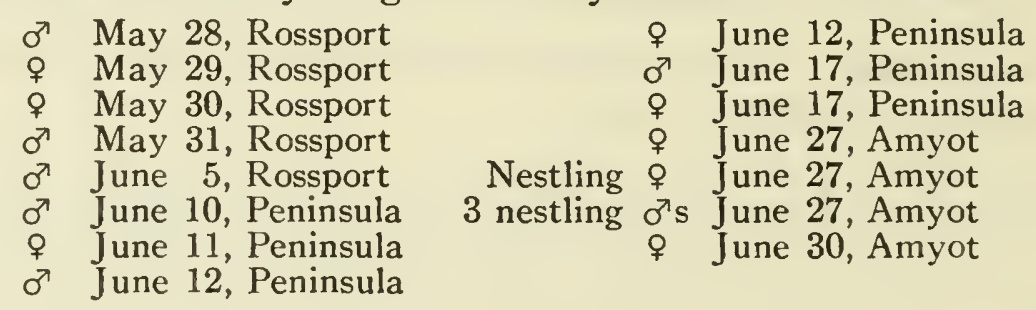

Melospiza lincolni. Lincoln's Sparrow.-This sparrow was not an uncommon summer resident of the region.

Definite breeding evidence was obtained at Amyot, where a juvenile just out of the nest was collected on June 29 .

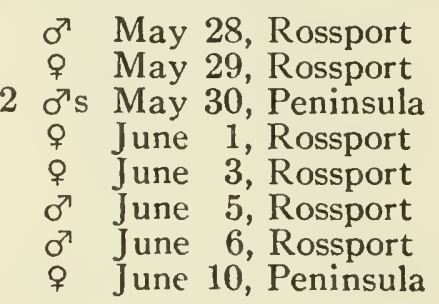

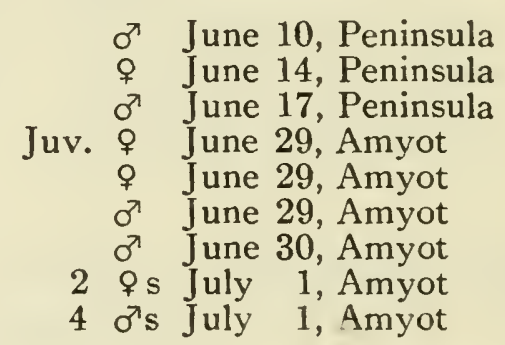


Melospiza georgiana. Swamp Sparrow.-The Swamp Sparrow was observed rarely at Rossport and Peninsula but rather commonly at Amyot, where as many as twenty adults were noted on June 26.
$\sigma^{7}$ June 3, Rossport
$\sigma^{7}$ June 13 , Peninsula
\& June 30 , Amyot

Melospiza melodia. Song Sparrow.-This was a common species at Rossport and Amyot but at Peninsula it was comparatively scarce.

A nest with five eggs was found on June 3 at Rossport and on June 25, at Amyot, a nest and five young, commencing to show feather-growth, was collected. Young out of the nest were observed first on July 4, at Amyot.

The form of Song Sparrow of this region has been referred to juddi (Fleming and Snyder, 1939).

\begin{tabular}{|c|c|c|c|}
\hline $0^{7} s$ & May 27, Rossport & $\sigma^{\pi}$ & June 20 , Peninsula \\
\hline $0^{7 x} s$ & May 28, Rossport & $2 \sigma^{7} s$ & June 24 , Amyot \\
\hline \%s & May 28 , Rossport & $2 \sigma^{7} \mathrm{~s}$ & June 25 , Amyot \\
\hline$\sigma^{2}$ & May 29 , Rossport & & June 25 , Amyot \\
\hline 9 & May 29 , Rossport & 4 nestling $\$ \mathrm{~s}$ & June 25 , Amyot \\
\hline $0^{7}$ & June 1 , Rossport & Nestling or & June 25 , Amyot \\
\hline Q & June 2 , Rossport & $\sigma^{7}$ & June 26 , Amyot \\
\hline$\sigma^{7}$ & June 4 , Rossport & ᄋ & June 26, Amyot \\
\hline$\sigma^{7}$ & June 5 , Rossport & $2 \sigma^{\top} s$ & Tune 27, Amyot \\
\hline $0^{7}$ & June 6 , Rossport & & une 30 , Amyot \\
\hline 우 & June 16 , Peninsula & Juv. & 4, Amyot \\
\hline 우 & insula & & \\
\hline
\end{tabular}

\section{LITERATURE CITED}

Agassiz, Louis. 1850. Lake Superior: its physical character, vegetation, and animals. Pp. 70-76, 99-108, 385.

American Ornithologists' Union. 1931. Check-list of North American birds.

Baillie, James L., Jr. and Paul Harrington. 1936-7. The distribution of breeding birds in Ontario. Trans. Roy. Can. Inst. 2I: Parts 1, and 2.

Dear, L. S. 1940. Breeding birds of the region of Thunder Bay, Lake Superior, Ontario. Trans. Roy. Can. Inst. 23: Part 1.

Fargo, William G. and Milton B. Trautman. 1930. Late summer bird notes along the upper Michipicoten River, Ontario. Can. Field-Nat. 44: 30-3.

Fleming, J. H. and L. L. Snyder. 1939. On Melospiza melodia in Ontario. Occ. Papers, R.O.M.Z. No. 5.

Halliday, W. E. D. 1937. A forest classification for Canada. Can. Dept. Mines and Res., Forest Service Bull. 89.

Peters, James L. and Ludlow Griscom. 1938. Geographical variation in the savannah sparrow. Bull. Mus. Comp. Zool. 80: 454-5.

Raine, Walter. 1892. Bird-nesting in North-west Canada, p. 12.

Ridgway, Robert. 1907. Birds of North and middle America, Vol. 4. Bull. U.S. Nat. Mus. 50: 67.

Saunders, W. E. 1922. Occurrence of the red-throated loon at Rossport, Ontario. Can. Field-Nat. 36: 137.

Sharpe, J.F. and J. A. Brodie. 1931. The forest resources of Ontario.

Snyder, L. L. 1928. The summer birds of Lake Nipigon. Trans. Roy. Can. Inst. I6: Part 2.

Snyder, L. L. 1938. Ontario and its avifauna. Con. R.O.M.Z. No. 12.

Snyder, L. L. 1942. Summer birds of the Sault Ste. Marie region, Ontario. Trans. Roy. Can. Inst. 24: Part 1.

Taverner, P. A. 1934. The birds of Canada. Nat. Mus. Can. Bull. 72.

Thompson, Ernest E. 1887. Canadian game and fish resorts. Forest and Stream 28: $42-3$.

White, James. 1916. Dictionary of altitudes in the Dominion of Canada (second edition). Commission of Conservation, Ottawa. 



\section{ROYAL ONTARIO MUSEUM OF ZOOLOGY}

This series contains reports of Museum studies, including faunal survey's. Except where otherwise stated the price is twenty-five cents a copy.

1. A Faunal Survey of the Lake Nipigon Region, Ontario, by J. R. Dymond, L. L. Snyder and E. B. S. Logier. 58 pages.

2. A Faunal Survey of the Lake Abitibi Region, Ontario, by the staff of the Royal Ontario Museum of Zoology. 46 pages.

3. A Faunal Investigation of King Township, York County, Ontario, by L. L. Snyder and E. B. S. Logier. 42 pages (out of print).

4. A Faunal Investigation of Long Point and Vicinity, Norfolk County, Ontario, by L. L. Snyder and E. B. S. Logier. 120 pages (out of print).

5. Some Account of the Amphibians and Reptiles of British Columbia, by E. B. S. Logier. 26 pages (out of print).

6. A study of the Sharp-tailed Grouse, by L. L. Snyder. 66 pages.

7. The Passenger Pigeon in Ontario, by Margaret H. Mitchell. Records of the history of the now extinct wild pigeon (Ectopistes migratorius) in Ontario. Paper, \$1.00. Cloth, \$1.50. 181 pages.

8. The Distribution of Breeding Birds in Ontario, by James L. Baillie, Jr., and Paul Harrington. 134 pages.

9. Some Freshwater Fishes of British Columbia, by J. R. Dymond. 14 pages.

10. The Birds of the Lake St. Martin Region, Manitoba, by T. M. Shortt and Sam Waller. 51 pages.

11. Baird's Sparrow, by B. W. Cartwright, T. M. Shortt and R. D. Harris. 44 pages.

12. Ontario and its Avifauna, by L. L. Snyder, and The Museum's Bird Collection, by J. L. Baillie. 14 pages.

13. Birds of Algonquin Provincial Park, Ontario, by D. A. MacLulich. 47 pages.

14. A Faunal Investigation of Western Rainy River District, Ontario, by L. L. Snyder. 57 pages.

15. The Fishes of the Ottawa Region, by J. R. Dymond. 43 pages.

16. The Birds of the Vicinity of Lake Nipissing, Ontario, by W. E. Ricker and C. H. D. Clarke. 25 pages.

17. The Summer Birds of Yakutat Bay, Alaska, by T. M. Shortt. 30 pages.

18. History of the Royal Ontario Museum of Zoology, by J. R. Dymond. 52 pages.

19. A Faunal Investigation of Prince Edward County, Ontario, by L. L. Snydar, E. B. S. Logier, T. B. Kurata, F. A. Urquhart, and J. F. Brimley. 123 pages.

20. The Blattaria and Orthoptera of Essex County, Ontario, by F. A. Urquhart. 32 pages.

21. A Faunal Investigation of the Sault Ste. Marie Region, Ontario, by L. L. Snyder, E. B. S. Logier and T. B. Kurata. 68 pages.

22. Some Recent Bird Records from Canada's Eastern Arctic, by T. M. Shortt and H. S. Peters. 11 pages.

23. The Summer Birds of the Northeast Shore of Lake Superior, Ontario, by J. L. Baillie, Jr. and C. E. Hope. 27 pages. 



$$
\begin{aligned}
& 261 \\
& 9063
\end{aligned}
$$






3iveryon

giving

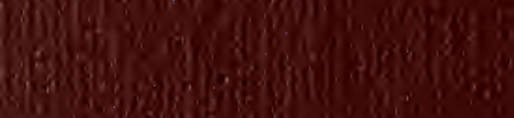

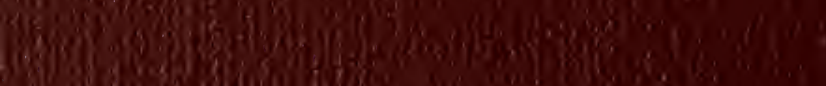

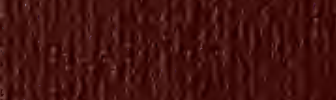

(3)

asciong

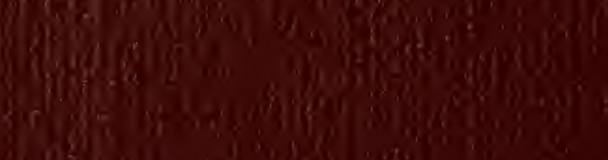

Was

Hor 